\title{
INHIBITION BY ERWINIA HERBICOLA EH252 OF BACTERIAL SOFT ROT DUE TO ERWINIA ON CARROT SLICES IN COMPOST
}

\author{
DEIRDRE A. CORNISH and JOEL L. VANNESTE
}

\author{
HortResearch, Ruakura Research Centre, Private Bag 3123, Hamilton
}

To determine the ability of Erwinia herbicola Eh252, to inhibit bacterial soft rot caused by Erwinia species, we compared the amount of rot on carrot slices treated or not treated with Eh252 after incubation in compost infected with Erwinia carotovora pv. carotovora. Compost was used to mimic the conditions under which bacterial soft rot develops and was preparedby mixing rotten carrot slices inoculated with Fcc 11523. When carrot slices were dipped in highly concentrated bacterial suspensions ofEh 252 , no rot was observed until five weeks incubation at $28^{\circ} \mathrm{C}$, while under the same conditions, $83 \%$ of slices dipped in $10 \mathrm{mM} \mathrm{MgSO}_{4}$, which was used as a control, were infected. After nine weeks of incubation 50\% of the carrot slices treated with Eh252 still showed no sign of infection. Lower concentrations of Eh252 conferred lower levels of protection. Eh252 produces an antibiotic-like molecule which in vitro inhibits all Erwinia species causing soft rot, and inhibits Eccl1523 on potato and carrot slices in laboratory assays. When carrot slices were dipped in a bacterial suspension of a non-antibiotic producing mutant of Eh252, protection was generally not as good as that conferred by Eh252. These results indicate that Eh252 can control soft rot on carrot slices in compost, and that one of the mechanisms involved is antibiotic production.

\section{SAPROPHYTIC SUPPRESSION OF BOTRYTIS CINEREA SPORULATION ON KIWIFRUIT LEAF TISSUE}

\author{
M.A WALTER ${ }^{1}$, P.A.G. ELMER ${ }^{1}$, K.S.H. BOYD-WILSON ${ }^{1}$, \\ J. PERRY ${ }^{1}$ and I. KOHL ${ }^{2}$ \\ ${ }^{I}$ The Horticulture and Food Research Institute Ltd. Canterbury Research Centre, \\ PO Box 51, Lincoln, New Zealand \\ ${ }^{2}$ DLU Research Inst itute for Plant Protection (IPO-DLO), P0 Box 9060, \\ Wageningen, The Netherlands
}

Stem end rot caused by Botrytis cinerea is the most important postharvest disease in the New Zealand kiwifruitprodUctiofl system. A collaborative research programme between HortResearch and IPO-DLO began in 1994 to screen saprophytic isolates of Alternaria, Chaetomium, Cladosporium, Epicoccum, Gliocladium and Ulocladium spp. for their ability to survive dry periods whilst suppressing $B$. cinerea sporulation on necrotic kiwifruit leaf tissue. Screening was carried out using laboratory, field and potted vine bioassays based upon tissue precolonised by $B$. cinerea. Results from all three assays were correlated $(\mathrm{P}<0.05)$. Botrytis suppression was highest for isolates of Alternaria, Epicoccum and Ulocladium spp. Although B. cinerea was given an advantage by precolonisation of tissue, suppression of $B$. cinerea sporulation by these isolates was similar or greater $(\mathrm{P}<0.05)$ than the standard fungicide (iprodione). The ability of selected saprophytes to suppress $B$. cinerea was affected $(\mathrm{P}<0.001)$. when the $B$. cinerea inoculum was applied either as a mixture of isolates or as single isolates. Results indicate that the laboratory screening technique is reliable for the initial selection of saprophytes capable of suppression of $B$. cinerea sporulation on necrotic kiwifruit leaf tissue. 